\title{
Review of US Policy towards Central Asia Under Trump Administration
}

\author{
Zhanna Dossan* PhD. Candidate \\ School of Political Science and Public Administration, Wuhan University, Wuhan, Hubei, 430072 China
}

\begin{abstract}
The research presents the review of US Policy towards Central Asia under Trump Administration. The research has used qualitative research design following the content analysis approach. The findings showed that the administrative policies offer few advantages to the Central Asia under Trump administration. The administrative policies of the US under Trump present that there are very few incentives for the Central Asia leaders as it risks its relationship with the new powerful neighbors. Also, the addition of the Kyrgyzstan in the list of countries for the citizens who are barred from applying for immigrant visas to the U.S. which also reinforcing this message. Although efforts are underway for the development of the Uzbekistan, this is not comparable to the capital flows from China and Russia. The findings showed that the United States must come forward and lead the administration for beginning evidence distribution activities to offer proper, criminal intelligence in chasing and prohibiting probable extremists in the region. Although Trump administrative efforts are aimed for a realistic success, these are found to be unrealistic for achieving the incentives.
\end{abstract}

Keywords: United States, Trafficking, Trump, Terrorism, Cyber

DOI: $10.7176 / \mathrm{JLPG} / 103-08$

Publication date: November $30^{\text {th }} 2020$

\section{Introduction}

The Soviet Union collapse has directed the US foreign policy in the new directed. Primarily, the relationship development process instigated with the five states of the Central Asia that had become newly independent. These five states include the Kazakhstan, Turkmenistan, Uzbekistan, Kyrgyzstan, as well as Tajikistan. Alred et al. (2017) has demonstrated that the US aims to help these newly independent states to establish the free-market institution, develop their energy resources, foster the democratic governance, develop national, economic as well as political institution as well as manage Soviet era WMD stockpiles (Hoem, 2020). Prior to the year 1991, the Central Asia states were observed to be marginal backwaters for the Washington. However, in the year 1990, following the dissolution of the Soviet Union, the Caspian Sea energy resources have attracted various oil firms in the US (Kucera, 2017). Consequently, the Caspian Basin energy resources led o emergence of the tension for the US and the Russia (Wilhelmsen\& Flikke, 2011). This eventually made the Central Asia as a battlefield on the War that is led by the US on the Terror. Various violent clashes are observed to emerge due to the different ethnic groups in the Uzbekistan, as well as groups in the Tajikistan (Kurtzleben, 2016). This eventually made the region more entangled with war in Afghanistan. However, the relationship that prevailed between the US and the Central Asia changed significantly after the incident of the September 2001, when the United States undertook a prolonged military campaign in the region with the global war framework against the terrorism (Alred et al., 2017). The United States have helped the countries in Central Asia to counter the actions and plans of the extremist group like the Islamic Movement of Uzbekistan (Micheal, 2016). The Pentagon has helped the militaries to become more effective, more efficient as well as more professional. The US agenda for the Central Asia as well as Afghanistan has included countering of the WND proliferation, to fight against the terrorist as well as to secure the borders (Lang, 2015). This also related to the advancement of the economic interest for the US, as well as regional integration following the promotion of the good governance, as well as civil liberties, monitoring of the activities related to the Russia, Chinese, Iranian activities along with the following and pursuing of the bilateral cooperation with each regional state (Kucera, 2015). The promotion of the human rights as well as democracy are found to be the main priorities of the governance of Obama administration in the Central Asia. This also included efforts related to the coupling with different conditions, as well as those that related to the security cooperation, primary focused on the fight against the violent extremism in the region.

As per the US state department country report related to the Human Rights Practices for the year 2016, an insufficient and inadequate level of the progress is found to exist for the democratic as well as human rights reform. The civil society repressions, and the press, religious, LGBT discrimination as well as lack of free as well as fair election continued to exist. As per the Freedom House of Human Right Index, following the exception of the Kyrgyzstan as it is ranked by the Index as Partly free, while the states that are included in the central Asia and ranked are not free. Along with it, a freedom rating has also been received from 5 to 7 (Alred et al., 2017). The administration of Obama spearheaded Annual Bilateral Consultations (ABCs) with the five countries for discussing a wide range of topics, comprising of the "counter-narcotics, democratic reforms, counterterrorism, the rule of law human rights, investment, trade, education as well as health. However, in the 
year 2012, the A BC discussion that were being held with the US and the Kazakhstan elevated and reached to a strategies partnership commission level. The administration of the Obama, continued with the formed Trade and Investment Framework Agreement (TIFA) which were established by the economic arrangement by the previous administration of the Bush. This was done in an effort of the enhancement of the regional integration following increase in the trade and the investments that are held between the Central Asia and the United States. The TIFA council comprises of representatives from the Central Asia and the US, which annually convenes the discussion of the multilateral collaboration in areas including the industry, energy, infrastructure, as well as trade.

The Central Asia continues the effective role related to the buffer zone as well as transit area of these regions. The region is found to comprise of various ethno-linguistic as well as religious groups that range from the Russia, Iran, China, and Afghanistan. The western extension of the Central Asia is presented by Turkey, concerning the boarder sphere of the culture. Lastly, the previous twenty years have observed the increasing economic, political, as well as military involvement in the new states of the Central Asia. This has led to the increased engagement of the Asian countries comprising of the Japan, India, South Korea as well as China, in the region.

\section{Aim, Scope and Method}

Although various studies have undergone the review of the US administration policies, however, the work is said to be limited concerning the questioning of the Trump administration policies that are to be pursued in the Central Asia remain unexplored. Despite the partnership of the Sino-Russia, the United States can in the near future can pursue its shared goals including cooperation of energy and regional security, which help to prevent against the instability in this potentially explosive region (Alred et al., 2017).Though, U.S. engagement with the region will likely remain secondary in comparison to the greater role of China and Russia in the region.

The methodology that is used for the analysis is qualitative, where the focus is on presenting the information which have been comprehensively discussed in the literature. The used technique in this research is labeled as documentary observation. Various scholars have presented that the technique helps in the systematic investigation of the existing records or the documents as the data sources. The technique is effective as it helps to collect the data where it is difficult to conduct the direct observations or the interview. Thereby, the review used this technique for reaching insightful information. The literature that is assessed in this work was selected through random sampling. The main rationale for the selection is based on the different administrative changes which have undergone in the US concerning the policies. Similarly, the use of the random sampling was based on its efficiency for collecting data in an adequate manner, efficient way, and easy to access capacity. The content analysis technique was used which is effective in the analysis of the comments, which is extracted from the text of the secondary sources. Given the sensitivity of the subject, this technique offers various benefits including the sample safety, as well as analysis. This helps to present the information that cannot be manipulated. The stated methods help to reach conclusive findings with no problems related to the safety for the research. Similarly, the same thing is applicable for the validating to the analyses.

\section{Results}

The analysis of the previous researches have shown that the focus of the administrative bodies have been central on the connectivity. This connectivity is based on the economic progression and strengthening of the independence of the central Asia from its neighbors'. However, the major focus of the US administrative bodies was to strip Central Asia of the resources offered. For instance, in the Clinton administration, the focus was determined to be on the energy sources that existed in the Caspia Sea (Mancoff, 2020). This was done in an hope to find new sources of oil, which would enable the countries such as Turkmenistan and Kazakhstan with sources that were able to provide them with new source of revenue (Kuchins, 2020). This also helps to set new pipelines to the Europe for improving the political and economic decoupling from the Russia. However, following the three decades, no such pipelines have been found to exists, however, the some oil is shipped through the ships from Kazakhstan to Europe. (Mancoff, 2020).

Similar practices are observed for the administration of Obama, where the focus was on the connection of the Central Asia with the South Asia, for enabling its competitiveness and competition against the Russia. The main accomplishment was the formation of the Northern Distribution Network, where the multilateral initiatives were issues for the establishment of the new transits for Afghanistan, in order to promote the regional integration for economic progression and strengthening in the Afghan economy (Schoenbaum, 2020). However, no such efforts were found on the practical grounds.

Reflecting on the main idea of the research such as administration under the president Donald Trump, the focus of the US is now shown to be more leaned towards the Central Asia for supporting its efforts to contain Russia, Iran, and primarily China (Mancoff, 2020). The new strategies formulated do not offer any central Asia strategy for maintaining central ties with the neighboring countries apart from the Afghanistan, where the senior officials of the US are found to be skeptical for the cooperation with the neighboring powers (Schacher, 2020). 
Another major reason which has been identified relates to the reforms that are required for boosting the economy through investment which appears to be contradictory to the economic influence of China. It has been reported in an article that American companies and investments serve as the response to the demand of sovereignty and independence (Mancoff, 2020). Mancoff (2020) has also indicated that this serves as the transactional approach which helps the Trump administration to send message to Europe, Japan and other allies of US concerning that they should make Washington as their selection rather than Beijing. This precisely relates to their choice concerning the selection of the Chinese companies for forming their $5 \mathrm{G}$ infrastructure. The central asia leaders are further seen to be in a challenging position with the renewed push for ending the involvement of the U.S. in Afghanistan, using the with-us-or-against-us message. This withdraw of the troops from the Afghanistan would end the strongest inducement of the American ties in the central Asia (Mancoff, 2020).

It is a surprise of the central Asia leaders to be skeptical concerning the prevalence of the China, Iran and Russia in the region despite the American disengagement. The administrative policies of the US under Trump present that there are very few incentives for the Central Asia leaders as it risks its relationship with the new powerful neighbors. Also, the addition of the Kyrgyzstan in the list of countries for the citizens who are barred from applying for immigrant visas to the U.S. which also reinforcing this message. Although efforts are underway for the development of the Uzbekistan, this is not comparable to the capital flows from China and Russia. Although Trump administrative efforts are aimed for a realistic success, these are found to be unrealistic for achieving the incentives (Mancoff, 2020).

Similarly, a survey of the studies associated with the management and handling of the relationships withthe Central Asia were studied. The previous studies showed the involvement of the US policy and its engagement in the Central Asia is driven to fight against the terrorism or not. This were done to ensure the elimination of the illicit activities such as drug trafficking which aids to finance the terrorism related activities. The analysis also emphasizes the involvement of the US policy and its engagement in the Central Asia is driven to make Afghanistan a safe heaven or not. Most of the studies in the survey showed that they agree to it being the reasons of involvement in the Central Asia (Kuchins, 2020). This is done to ensure the regional stability due to which the US maintains its military presence. The studies also showed the involvement of the US policy and its engagement in the Central Asia is driven to stop drug trafficking or not. The studies also showed it being the reasons of involvement in the Central Asia. This is done to ensure the halting of the drug trafficking in the Central Asia. The studies also showed the involvement of the US policy and its engagement in the Central Asia is driven to stop economic isolation. This is done to ensure the economic integration across different sectors in the Central Asia (Hoem, 2020).

The participants were asked whether the involvement of the US policy and its engagement in the Central Asia is driven to overcome human rights restrictions in Central Asia. Most of the studies in the survey showed that the involvement of the US policy and its engagement in the Central Asia is driven to overcome human rights restrictions in Central Asia. The studies showed that the involvement of the US policy and its engagement in the Central Asia found to be challenging due to the hostility of the Russia and China towards it. Primarily, the analysis showed that they agree to it being the challenging for the integration in the Central Asia. (Hoem, 2020) also emphasized the involvement of the US policy and its engagement in the Central Asia found to be challenging due to the restrictions on religious and other freedoms due partly to counterterrorism concerns. The US policy and its engagement in the Central Asia found to be challenging due to the integration of the various other external powers such as Japan, Russia and China. Most of the respondents in the survey showed that they agree to it being the challenging for the integration in the Central Asia. Similarly, the research of Hoem (2020) showed that the U.S. limited involvement compared to other external players (like Japan, Russia and China). (Alredet al., 2017) highlights that the involvement of the US policy and its engagement in the Central Asia found to be challenging due to the .S. business indifference and ignorance of toward regional commercial opportunities beyond the energy. Along with the U.S. business indifference and ignorance of toward regional commercial opportunities beyond the energy sector

\section{Discussion and Recommendation}

To control the movement of the extremists around Central Asia, the U.S. must improvise the aptitude, law implementation, and safety methods in the region. The UN Security Council Resolution 2178 that need republics to initiate concrete measures to handle the risk of overseas extremist's battalions (comprising averting them from arriving or roving via their areas) is not assisted by passable official intelligence-and-information-sharing arrangements. The United States must come forward and lead the administration for beginning evidence distribution activities to offer proper, criminal intelligence in chasing and prohibiting probable extremists in the region. The collaboration of European and Central Asian intelligence will assist in backing the counterextremism law implementation rule globally, prepared with protected communications systems, databanks, and a method of notifications that involves methodologies to chase illegal money laundering, theft and fake identity documents, and travel papers. This is exclusively right in the situation of Central Asian extremism, as maximum 
illegal money laundering for militancy and tranquillizers happen virtually. Central Asian control problem portray a basic cause of regional extremism. Dishonesty and dictatorial inclinations of administrations, restricted community sovereignties, growing poverty and marginalization, including the plea of terrorist religious believed back to better onboarding of extremist. Subsequently, any U.S. plan in Central Asia must be assisted by the improvisation in management policies. In particular, the United States should emphasize on 'bottom-up' control; Central Asian peoples frequently grip bigger loyalty to native, cultural, and spiritual frontrunners over the elected governments, and the governmental authorities' features develop a distrust between the civil society clusters. In this manner, the United States can emphasize nurturing beliefs that can block extremist onboarding and extremists' acts. The United States can motivate domestic creativities intended to offer marginalized youth with occupational expertise development, hiring chances, and English linguistic services. In many unstable zones, madrassa pupil's scarce adequate engagement chances are effortlessly employed into extremist clusters. In Kyrgyzstan, minor struggles at offering youth with work-related expertise appear to be effective and must be extended around the region. Furthermore, the United States can emphasize the support to Central Asian societies to assist in improvising foodstuff retreat, irrigation, and farming practices. In Tajikistan, USAID's implemented the forthcoming good steps with Tajik societies in upgrading the quality and amount of their harvests, which escalates families' revenues, and assisted the cultures that deject youth from extremist deeds. U.S. ventures like these must be executed around the region to initiate same struggle and outcomes. The United States can also support global and domestic NGOs with ventures surrounding by motivating the families, particularly the mothers, to recognize and handle the symbols of radicalism in their societies' youth. In Central Asian relations, mothers are specifically powerful in the development of their wards, and offering them with the expertise to dishearten radicalization of family members is vibrant. A current test venture sideways these outlines planned by the Organization for Security and Cooperation in Europe's Countering Violent Extremism (OSCE CVE) inventiveness is in progress, and, if fruitful, must be executed around the region. The United States can also provide help and back and developing to domestic and cultural frontrunners in the areas of skirmish resolution and safety. The power of cultural and communal bonds in Central Asian community frequently gives domestic players with superior customary rightfulness. As minor gauge creativities in Kazakhstan, Kyrgyzstan, Uzbekistan, and Tajikistan validate, founding creativities that authorize and develop communal frontrunners who compete against extremism is vital and could be an important instrument in avoiding fanaticism, demotivating extremist enrollment, and solving encounter. Confirming that these creativities are widened and vigorously sponsored is significant to U.S. energies in opposing extremism. The U.S. can endorse reasonable Muslim leaders who are resilient to Religious fundamentalism and extremism on the domestic, global and regional level. While marginalization and scarcity of financial openings for Central Asians are core reasons for extremist deployment, spiritual fundamentalism is a dominant immediate reason. Many marginalized youths are involved in extremist clusters because of the attraction of an "idealistic" religious caliphate or a "sacred battle" against Western and controlling government inclinations.Struggles to contest this storyline must be dominant. The dictatorial nature of Central Asian governments has caused in the elevation of an authorized, the state forced, and reasonable brand of Islam that is forced upon peoples by power, and discards any other exercise of the religion. It competes with sovereign spiritual appearance, irrespective of whether that appearance is reasonable or radical. In the situation of the Middle East, dictatorial inclinations caused in superior political disagreement that frequently overlapped with more dangerous spiritual believed. The same outcome in Central Asia is probable. A dictatorial notion of faith will only generate superior public reaction organized by aggressive spiritual clusters. Subsequently, the United States has an attentiveness in helping and endorsing spiritual leaders who are against extremists' strategies. Creativities, in addition to these lines, can help in assuring that spiritual person are not drawn to extremism and connected fierceness as an opening for governmental appearance. The United States must motivate struggles by Central Asian governments to minimize dishonesty, strict to the law obedience and leverage the people sovereignty and human rights, and motivating increasing trade; visa leverages, and interregional business (Alredet al., 2017). Where these objectives need significant time and struggle, going ahead in this direction will initiate a higher implementation of anti-extremism laws, minimum rewards for the persons to recourse to violence as a means for governmental disapproval, and initiate financial openings that minimize the interest of extremist'sactions. Further, the United States must motivate Turkey to work together more with Central Asian countries in this intellect sharing struggle by re-evaluating its generous travel controls. Recently, workers and resources can move with comfort from the Levant over Turkey, and the Caucasus via northern Iran and into Afghanistan (Micheal, 2016). Moving to Turkey doesn't need any visa for peoples of Kazakhstan, Kyrgyzstan, Tajikistan, and Turkmenistan; Uzbeks have a 30-day visa on arrival. As a NATO partner, Turkey must be grateful to work together in this struggle to confirm border safety, so that law implementing administrators along this way and in Central Asia can recognize and impeach potential extremists.

\section{References}

Alred, L., Kelly, S. M., Rubly, M., Shokh, Y., Tsitsishvili, M., \& Weitz, R. (2017). US Policy Towards Central 
Asia under Trump. Revista UNISCI, (45), 41-66.

Hoem, T. B. (2020). The End of Engagement: US Foreign Policy Towards China, From Obama Through Trump (Master's thesis).

Kucera, J. (2015). U.S. Defends Giving Armored Vehicles to Uzbekistan. Eurasianet, at http://www.Eurasianet.Org/Node/74126.

Mancoff. (2020). Trump's New Central Asia Strategy Aims to Be Realist. But It's Unrealistic. Available at: https://www.worldpoliticsreview.com/articles/28628/trump-s-new-central-asia-strategy-aims-to-be-realistbut-it-s-unrealistic

Kucera, J. (2017). U.S. Boosts Special Forces Training in Central Asia. Eurasianet [http://www.eurasianet.org/node/83021]

Kuchins, A. C. (2020). What is Eurasia to US (the US)?. In The "Roads" and "Belts" of Eurasia (pp. 333-354). Palgrave Macmillan, Singapore.

Schacher, Y. (2020). Family separation and lives in limbo: US immigration policy in the 1920s and during the Trump administration. The ANNALS of the American Academy of Political and Social Science, 690(1), 192199.

Schoenbaum, T. J. (2020). The Art of the Deal and North American Free Trade: Advantage for the United States. Ohio St. Bus. LJ, 14, 100.

Kurtzleben, D. (2016). Chart: How the U.S. Troop Levels in Afghanistan Have Changed Under Obama. at http://www.npr.org/2016/07/06/484979294/chart-howthe-u-s-troop-levels-in-afghanistan-have-changedunder-obama

Lang, J. (2015). The Luftwaffe and American Military Equipment in Uzbekistan. Available at https://www.osw.waw.pl/en/publikacje/analyses/2015-02-04/luftwaffe-andamerican-military-equipmentuzbekistan

Micheal, C. (2016). What to Expect From US Central Asia Policy Under President Trump Available at:https://thediplomat.com/2016/11/what-to-expect-from-us-central-asia-policy-under-president-trump/

Wilhelmsen, J., \& Flikke, G. (2011). Chinese-Russian convergence and central Asia. Geopolitics, 16(4), 865901. 